\title{
Laboratory profile of malnutrition in hospitalized dogs
}

\section{Perfil laboratorial da desnutrição em cães hospitalizados}

\author{
Andrei Kelliton Fabretti ${ }^{1 *}$; Raquel Carolina Simões Siqueira ${ }^{2}$; \\ Higo Forlan Amaral ${ }^{3}$; Lucas Alécio Gomes"; Danielle Venturini6; \\ Patrícia Mendes Pereira ${ }^{4}$
}

\section{Highlights}

There is an association between malnutrition and disease severity. Iron metabolism marker proteins indicate nutritional status in dogs.

Cholesterol and albumin are not good markers of nutritional status in dogs.

\begin{abstract}
Malnutrition occurs when the supply of available nutrients is less than organic demand. It is an underdiagnosed problem in veterinary medicine and can result in several negative metabolic consequences, with greater morbidity and mortality. Currently, the classification of nutritional status (NS) is performed subjectively in veterinary medicine, so studies and discoveries about laboratory markers (objectives) of malnutrition are desirable. This study evaluated the correlations between several laboratory variables (practical and lowcost measurements) and the nutritional status (NS) of 246 dogs from a veterinary school hospital in southern Brazil. In this way, the laboratory profile of malnutrition in this population is evident. NS was classified by body condition score (BCS) and muscle mass score (MMS). A patient was considered to be malnourished if the BCS was less than 3 (values from 1 to 9). The laboratory variables analyzed were hemogram, cholesterol, total protein (TP), albumin, C-reactive protein (CRP), CRP/albumin ratio, total iron-binding capacity (TIBC), transferrin (TF), transferrin saturation index (TSI), and transthyretin. The means and standard deviations of the variables, correlation analyses, and comparative analyses (Kruskal-Wallis in $\alpha=5 \%$ ) were calculated. This research aimed to identify objective and practical malnutrition markers that help in the elaboration of a protocol for nutritional evaluation in diseased dogs. Low values of TF, TIBC, TP, hemogram, and TSI elevation were indicative of malnutrition. Additionally, cholesterol and albuminemia are not good markers

1 Prof. Dr., Faculty of Veterinary Medicine and Animal Science, Universidade Federal do Mato Grosso do Sul, UFMS, Campo Grande, MS, Brazil. E-mail: andrei.fabretti@ufms.br

2 Veterinary, Londrina, PR, Brazil. E-mail: raquelcarolina.vetuel@gmail.com

3 Prof. Dr., Universidade Estadual de Maringá, UEM, Maringá, PR, Brazil. E-mail: higoamaral@gmail.com

4 Profs. Drs., Department of Veterinary Clinics, Universidade Estadual de Londrina, UEL, PR, Brazil. E-mail: lucasalecio@ gmail.com; pmendes@uel.br

5 Profa Dra, Department of Pathology, Clinical and Toxicological Analysis, UEL, PR, Brazil. E-mail: daniventurini@uel.br

* Author for correspondence
\end{abstract}

Received: Mar. 03, 2021 - Approved: July 22, 2021 
of malnutrition in dogs with systemic diseases. For the graduation of the inflammatory state (important to differentiate inflammatory hypoproteinemia from protein malnutrition), it is more reliable to measure the CRP/albumin ratio. Canine transthyretin cannot be measured with reagents designed for humans, such as those used in this study. It was possible to conclude that laboratory indicators of malnutrition in sick dogs include low values of TF, TIBC, and TP, anemia, and elevations of TSI. The joint changes in these markers gradually reinforced the diagnosis.

Key words: Nutritional assessment. Malnutrition. Iron metabolism. Transferrin.

\section{Resumo}

A desnutrição ocorre quando a oferta de nutrientes disponíveis é inferior à demanda orgânica. É um problema subdiagnosticado em medicina veterinária e pode resultar em diversas consequências metabólicas negativas, com maior morbidade e mortalidade. Atualmente, a classificação do estado nutricional (EN) é feita subjetivamente na medicina veterinária, de maneira que estudos e descobertas sobre marcadores laboratoriais objetivos de desnutrição são desejáveis. O propósito da pesquisa foi encontrar marcadores de desnutrição objetivos e práticos que ajudem na elaboração de protocolos de avaliação nutricional em cães doentes. Este estudo avaliou as correlações entre diversas variáveis laboratoriais (de mensurações práticas e de baixo custo) com o estado nutricional (EN) de 246 cães de um hospital veterinário escola do sul do Brasil, evidenciando o perfil laboratorial da desnutrição desta população. O EN foi classificado por meio do escore de condição corporal (ECC) e escore de massa muscular (EMM). Foram considerados desnutridos os animais com ECC $\leq 3$ (Laflamme, 1997) ou EMM $\leq$ 2 (World Small Animal Veterinary Association [WSAVA], 2013). As variáveis laboratoriais analisadas foram: hemograma, colesterol, proteína total $(\mathrm{PT})$, albumina, proteína $C$ reativa $(\mathrm{PCR})$, relação PCR/albumina, capacidade total de ligação com ferro (CTLF), transferrina (TF), índice de saturação da transferrina (IST) e transtirretina. Foram calculadas as médias e desvios-padrões das variáveis, análises de correlação e análises comparativas (Kruskal-Wallis em $\alpha=5 \%$ ). Foram indicativos de desnutrição: baixos valores de TF, CTLF e PT, anemia e elevações da IST. Ademais, o colesterol e a albumina não são bons marcadores de desnutrição em cães com doenças sistêmicas. Para a graduação do estado inflamatório (importante para diferenciar hipoproteinemia inflamatória da desnutrição proteica), é mais confiável a mensuração da relação PCR/albumina. A transtirretina canina não pode ser mensurada com reagentes elaborados para humanos, como os utilizados nesta pesquisa. Foi possível concluir que são indicadores laboratoriais da desnutrição em cães doentes: baixos valores de TF, CTLF e PT, anemia e elevações da IST. As alterações conjuntas desses marcadores reforçam gradativamente o diagnóstico.

Palavras-chave: Avaliação nutricional. Má-nutrição. Metabolismo do ferro. Transferrina. 


\section{Introduction}

Malnutrition is a metabolic condition associated with a poor prognosis (Saker \& Remillard, 2010; Fabretti et al., 2014). It occurs when the supply of available nutrients does not meet the organic demand, and its severity is proportional to the extent and duration of the dietary deficit or the intensity of losses through endogenous pathways. This is a common but underdiagnosed condition (Saker \& Remillard, 2010; Fabretti, Fonseca, Coelho, Silva, \& Pereira, 2015; Gagne \& Wakshlag, 2015; Keller, 2019).

As it progresses, malnutrition begins to affect physical health, manifesting as thinness, muscle weakness, and poor appearance of the skin and coat, in addition to various metabolic changes (Chandler \& GunnMoore, 2004; Fabretti et al., 2015; Gagne \& Wakshlag, 2015). Among the damage caused by malnutrition in health, there is a substantial reported delay in healing, immunosuppression, and, consequently, greater predisposition to serious diseases, long periods of hospitalization, and higher mortality (De Luis et al., 2006; Lim et al., 2012; Agarwal et al., 2013; Corkins et al., 2014; Fabretti et al., 2014; Slee, Birch, \& Stokoe, 2016). Consequently, it is common for health expenses to be higher for malnourished patients (De Luis et al., 2006; Lim et al., 2012; Corbee \& Kerkhoven, 2014; Corkins et al., 2014; Slee et al., 2016).

Approximately $50-60 \%$ of humans and animal patients are malnourished, and this precarious nutritional status (NS) tends to worsen during hospitalization. Thus, a strong association between malnutrition and disease is evident (Chandler \& Gunn-Moore, 2004; Hébuterne et al., 2014; Fabretti et al.,
2015; Bazzi et al., 2016). The advantage of recognizing malnourished patients is that they allow the development of nutritional protocols that reverse this situation, thereby improving the prognosis (Fabretti et al., 2014; Brunetto \& Carcioffi, 2015; Michel, 2015, 2017).

Because of these factors, the assessment of the NS in companion animals is categorized as one of the five vital parameters that must be evaluated in every patient visit (Baldwin et al., 2010; Freeman et al., 2011). However, a sensitive, specific and an early gold standard for the diagnosis of malnutrition has not yet been established (Fabretti, Siqueira, Chaves, Camacho, \& Pereira, 2018). One limitation is that veterinary medicine has fewer options than human medicine for evaluating NS. The variation in physical size and body conformation between different dog breeds limits the use of morphometric measurements and standardization of physical examination techniques for the study of NS (Fabretti et al., 2015, 2018). Consequently, the goal is the discovery of accessible and low-cost laboratory markers of NS, which are practical for professional routine use. Recently, in human medicine, there has been a focus on studies with short half-life serum proteins, such as transferrin (TF), an iron transporter, and transthyretin (TTR), a thyroxine transporter, as they indicate the changes in patients' NS faster (Sullivan, 2001; Szöke \& Panteghini, 2012; Ingenbleek \& Bernstein, 2015).

Briefly, the causes of reduction in serum protein include inflammation, nephrotic syndrome, protein wasting enteritis, burns, and protein malnutrition, whereas elevation occurs due to dehydration (relative increase) and hyperglobulinemia, which can be associated with inflammatory, neoplastic, and immune- 
mediated diseases (Bush, 2004; Cooper, Penne, Bartlett, \& Pollock, 2004; Sullivan, 2001). TF and TTR are less influenced by extra nutritional factors than albumin (Nakajima et al., 2012; Szöke \& Panteghini, 2012; Nakajima, Ohno, Goto-Koshino, Fujino, \& Tsujimoto, 2014; Ingenbleek \& Bernstein, 2015; Fabretti et al., 2018; Keller, 2019).

To date, few studies have objectively evaluated TF in dogs (Nakajima et al., 2012, 2014; Ingenbleek, 2019). One difficulty in using TTR in dogs is that performing the measurements involves using imported and expensive reagents.

Although NS markers are useful, they all have limitations, such as lack of specificity (Keller, 2019). However, the simultaneous use of several assessment methods makes the diagnosis of NS more reliable (De Luis et al., 2006; Maicá \& Schweigert, 2008; Sullivan, 2001). Many laboratory NS markers are also negative acute-phase proteins, so it is critical to measure them together with inflammation markers. This posture allows us to differentiate inflammation-associated reduction of these proteins from malnutrition-associated reduction (Bally et al., 2016; Felder et al., 2016). C-reactive protein (CRP) is the most used for this purpose (Kuribayashi et al., 2003; Tvarijonaviciute, Martinez, Gutierrez, Ceron, \& Tecles, 2011; Richards et al., 2012; Bally et al., 2016).

Therefore, this study aimed to evaluate the correlations between several laboratory variables (from practical and routine measurements, except for transthyretin) with the NS of hospitalized dogs. In this way, we present the laboratory profile of malnutrition in this population. CRP levels were measured to determine the patients' inflammatory levels. Consequently, we intend to generate information that will help in the development of protocols for the identification of malnutrition in sick dogs.

\section{Material and Methods}

The study was conducted with patient dogs from a veterinary hospital in southern Brazil. The project was approved by the institution's ethics committee under registration 1679/2013. Dogs that attended from June 2013 to November 2016 were considered for inclusion, without distinction of sex, age, or breed. The exclusion criteria were designed to avoid situations in which serum proteins were altered by extra nutritional factors, such as clinical dehydration greater than 7\%, patients undergoing blood transfusion up to 21 days before the evaluation, patients treated with parenteral nutrition, and cases of nephropathies or hepatopathies with cirrhosis. Other factors that influence serum protein levels are infectious diseases, neoplasms, enteritis, skin burns, and malnutrition. Animals at risk of complications due to handling stress or blood collection, such as dyspneic, aggressive, and under $2 \mathrm{~kg}$ of body weight, were also excluded from the study. Additionally, animals whose owners did not agree with the study were not included in the study.

Data collection and physical and laboratory assessments were performed within $48 \mathrm{~h}$ of hospital admission. The following patient data were recorded: race, age, sex, and reason for admission. To determine the body condition score (BCS), dogs were classified on a nine-grade scale (Laflamme, 1997). The classification of muscle mass score (MMS) 
was performed on a four-grade scale (WSAVA, 2013). Scores were classified by a single trained veterinarian. Patients with $\mathrm{BCS} \leq 3$ and MMS $\leq 2$ were considered malnourished.

The animals were also evaluated for underlying disease severity and clinical signs, which were used to distribute the animals into three groups. The first group (G1) comprised 96 dogs without systemic diseases. The second group (G2) comprised 80 dogs with non-disabling systemic diseases; that is, systemic conditions that did not prevent them from walking, at least for short distances. The third group (G3) comprised 70 dogs with critical and disabling systemic diseases, in which the dogs remained in obligatory recumbency. Admissions were made based on the sole decision of the veterinarian responsible for the case, without any involvement in the research.

Soon after the physical examination, blood was collected for laboratory tests carried out at the same institution. The erythrogram and total leukocyte counts were performed using an automated device BC-2800VET, Mindray ${ }^{\circledR}$ (Mindray do BrasilComércio e Distribuição de Equipamentos Médicos Ltda, São Paulo, SP). Platelet counts and leukocyte differentials were determined using optical microscopy. Serum was separated by centrifugation, stored in disposable polypropylene tubes, and frozen at $-80^{\circ} \mathrm{C}$ until the analysis was conducted.

Albumin was assessed using the bromocresol green method, analyzed by the semi-automatic device BIO - 2000, from

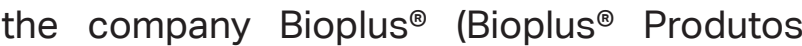
para Laboratórios Ltda, Baurueri - SP), using colorimetric tests with kits from the brand, Belo Horizonte, MG). The other biochemical measurements were performed using a
Siemens Dimensions automated device (model $\mathrm{RXL}$ ) with enzymatic/colorimetric test reagents from the company Siemens ${ }^{\circledR}$ (Siemens AG, São Paulo, SP) analyzed by the spectrophotometric method, according to the manufacturer's instructions. Using the same apparatus and reagents from the aforementioned company, PCR was conducted using the ultrasensitive turbidimetric immunoassay technique. From the TIBC values, the TF was calculated using the following formula: TF $\left(m g d L^{-1}\right)=\operatorname{TIBC} \times 0.7$ (Pires, Dittrich, Souza, Bertol, \& Patrício, 2011; Szöke \& Panteghini, 2012). This calculation was used because commercially available reagents for the determination of human TF do not show good reproducibility in the canine species and specific reagents imported for dogs are expensive, and inaccessible in our country (Saker \& Remillard, 2010; Pires et al., 2011; Bohn, 2015).

The TF saturation index (TSI) was determined using the following formula: TSI $(\%)=100 \times$ Iron/TIBC $($ Pires et al., 2011; Veena, Amit, Sonagra, Rekha, \& Jayaprakash, 2013). Due to the lack of commercially available reagents for measuring canine TTR in our country, a pilot test was conducted with reagents intended for human use (Siemens ${ }^{\circledR}$ DF80) with canine serum. The laboratory teams did not have access to the results of physical examinations and experimental groups of the animals from which the blood came, being blind to the nutritional status and prognosis of the dogs studied.

Two approaches were used for statistical analysis. For both, the Action Stat $\mathrm{Pro}^{\circledR}$ statistical software was used. First, considering the possible equalities/ differences between the means of the variables, the Kruskal-Wallis analysis 
was applied. Subsequently, the minimum significant difference was calculated using the $\mathrm{H}$ test, considering an error level $(\alpha)$ of $5 \%$ (Pimentel-Gomes, 2009). Second, correlation analysis ( $r$ ) was applied between quantitative variables to ascertain the strength between them (Spearman correlation) (Wissler, 1905). Next, a hypothesis test $(p=0)$ was applied to the correlation coefficient, which has a t-test (Bussab \& Morettin, 2013).

\section{Results and Discussion}

The sample analyzed, after following the inclusion and exclusion criteria originally proposed, consisted of 246 dogs.

\section{Description of groups}

A total of 96 animals were evaluated in G1. Of these, $42.70 \%(41 / 96)$ were male and $57.30 \%$ (55/96) were female, 36.45\% (35/96) were mixed-breed dogs (MBD), and $63.55 \%(61 / 96)$ were various races. Age and mean weight were 70 months and 15.14 $\mathrm{kg}$, respectively. The frequency of thinness (BCS $\leq 3$ ) was $9.38 \%$ (9/96) and the low lean mass (MMS $\leq 2$ ) was $14.58 \%$ (14/96). Regarding the reasons for attending, 38.54\% (37/96) attended the veterinary hospital for elective orchiectomy or ovariohysterectomy, $22.92 \%$ (22/96) for check-up examinations, $22.92 \%(22 / 96)$ for the evaluation of localized dermatopathies, and $15.62 \%$ (15/96) for other reasons not associated with systemic diseases.
Eighty animals were evaluated in the G2. Of these, $43.75 \%$ (35/80) were male and $56.25 \%(45 / 80)$ were female, $45 \%$ (36/80) were MBD, and $55 \%(44 / 80)$ were of diverse purebreds. The age and average weight were 57.46 months and $13.37 \mathrm{~kg}$, respectively. The frequency of thinness was $27.50 \%$ (22/80), and the low lean mass was $37.50 \%(30 / 80)$. In this group, $33.75 \%$ (27/80) were treated for acute gastroenteritis, $7.5 \%$ (6/80) for pyometra, $3.75 \%(3 / 80)$ for pancreatitis, and the remaining $55 \%(44 / 80)$ due to the presence of several non-disabling systemic diseases.

G3 comprised of 70 animals. Of these, $60 \%(42 / 70)$ were male and $40 \%(28 / 70)$ were female, $60 \%(42 / 70)$ were MBD, and $40 \%$ $(28 / 70)$ were of different breeds. The age and mean weight were 92 months and 12 $\mathrm{kg}$, respectively. In this group, $40 \%$ were thin (28/70), and $80 \%$ had low muscle mass (56/70). These animals were treated for neoplasms in $17.14 \%(12 / 70)$ of the cases, heart diseases without associated kidney disease in $12.85 \%$ (9/70), canine monocytic ehrlichiosis in $11.43 \%(8 / 70)$ and $58.58 \%(41 / 70)$ due to other critical systemic diseases.

In each group, the correlation of serum hematological and biochemical variables with the NS assessment parameters (BCS and MMS) was tested. A comparative description of the variables analyzed by means is presented in Table 1. The statistically significant correlations ( $p<0.05$ ) for $G 1, G 2$, and G3 are shown in Table 2. 
Table 1

Comparative analysis of laboratory variables between groups of dogs without systemic diseases (group 1 = G1), with non-disabling systemic diseases (group $2=\mathrm{G} 2$ ) and disabling diseases (group $3=$ G3)

\begin{tabular}{|c|c|c|c|c|}
\hline Variables & G1 (n=96) & $\mathrm{G} 2(\mathrm{n}=80)$ & G3 $(n=70)$ & Reference range \\
\hline Erythrocytes (106 $\mu \mathrm{L})$ & $\# 6,40 \pm 1,26 a$ & $5,43 \pm 0,18 b$ & $4,69 \pm 2,10 \mathrm{c}$ & $5,5-8,5^{*}$ \\
\hline Hematocrit (\%) & $40,15 \pm 7,73 a$ & $33,16 \pm 9,78 b$ & $27,99 \pm 1,6 c$ & $37-55^{*}$ \\
\hline Hemoglobin (g dL-1) & $13,58 \pm 2,94 a$ & $10,94 \pm 3,52 b$ & $9,39 \pm 4,17 \mathrm{c}$ & $12-18^{*}$ \\
\hline MCV (fL) & $62,48 \pm 3,47 a$ & $61,19 \pm 4,00 a$ & $60,40 \pm 4,51 a$ & $60-77^{*}$ \\
\hline $\mathrm{MCH}(\mathrm{pg})$ & $21,20 \pm 1,84 a$ & $20,03 \pm 1,98 a$ & $20,08 \pm 3,31 a$ & $19-23^{*}$ \\
\hline MCHC (\%) & $33,89 \pm 2,36 a$ & $32,83 \pm 2,73 a$ & $33,56 \pm 3,60 a$ & $32-36^{*}$ \\
\hline Total Leukocytes $(\mu \mathrm{L})$ & $10.529 \pm 4498 a$ & $10.400 \pm 4208 a$ & $13.500 \pm 9964 b$ & $6.000-17.000^{*}$ \\
\hline Segmented neutrophils $(\mu \mathrm{L})$ & $8763 \pm 3403 a$ & $8491 \pm 3736 b$ & $11.163 \pm 9835 \mathrm{c}$ & $3.000-11.500^{*}$ \\
\hline Lymphocytes ( $\mu \mathrm{L})$ & $2.398 \pm 1.464 \mathrm{a}$ & $2.167 \pm 1.964 b$ & $1.336 \pm 1.113 c$ & $1.000-4.800^{*}$ \\
\hline Eosinophils $(\mu \mathrm{L})$ & $792 \pm 927 a$ & $544 \pm 854 b$ & $280 \pm 202 c$ & $100-1.250^{*}$ \\
\hline Monocytes $(\mu \mathrm{L})$ & $349 \pm 172 a$ & $350 \pm 309 a$ & $313 \pm 394 a$ & $150-1350^{*}$ \\
\hline Platelets (106 $\mu \mathrm{L})$ & $490 \pm 232 a$ & $409 \pm 223 b$ & $341 \pm 255 c$ & $200-500^{*}$ \\
\hline Transferrin (mg dL') & $254,50 \pm 76,10 a$ & $211,92 \pm 76,22 b$ & $223,18 \pm 99,46$ b & $228,5-291,1^{* *}$ \\
\hline TBIC ( $\left.\mu \mathrm{g} \mathrm{dL}^{-1}\right)$ & $363,57 \pm 108,72 \mathrm{a}$ & $302,75 \pm 108,89 b$ & $318,83 \pm 142,08 b$ & $326,4-415,8^{* *}$ \\
\hline TSI (\%) & $35,79 \pm 14,88 a$ & $42,97 \pm 23,89 a b$ & $47,73 \pm 23,94 b$ & $34,8-46,1^{\text {** }}$ \\
\hline Total Protein $\left(\mathrm{g} \mathrm{dL}^{-1}\right)$ & $6,42 \pm 1,48 a$ & $6,36 \pm 1,73 a$ & $6,26 \pm 1,66 a$ & $5,5-8,0^{*}$ \\
\hline Albumin $\left(\mathrm{g} \mathrm{dL}^{-1}\right)$ & $3,13 \pm 1,24 a$ & $2,54 \pm 0,90 b$ & $2,20 \pm 1,03 b$ & $2,6-3,3^{*}$ \\
\hline Globulin & $3,29 \pm 1,57 a$ & $3,75 \pm 1,93 a b$ & $3,97 \pm 1,62 b$ & $2,7-4,4^{*}$ \\
\hline CRP $\left(\mu \mathrm{g} \mathrm{mL}^{-1}\right)$ & $2,13 \pm 1,36 a$ & $3,61 \pm 1,73 b$ & $4,97 \pm 7,01 \mathrm{c}$ & $<5,05-8,70^{* * *}$ \\
\hline CRP/albumin & $0,90 \pm 1,09 a$ & $1,81 \pm 1,72 b$ & $2,62 \pm 2,80 \mathrm{c}$ & - \\
\hline Cholesterol (mg dL-1) & $217,17 \pm 69,67 \mathrm{a}$ & $220,86 \pm 84,74 a$ & $238,76 \pm 140,90 a$ & $135-270^{*}$ \\
\hline
\end{tabular}

\#Means \pm standard deviation, with equal letters, there are no differences between groups of dogs, $\mathrm{H}$ test level of error $5 \%$. MCV, mean corpuscular volume; $\mathrm{MCH}$, mean corpuscular hemoglobin; MCHC, mean corpuscular hemoglobin concentration; TBIC, total iron binding capacity; TSI, transferrin saturation index; CRP, C-reactive protein. * Kaneko, Harvey, \& Bruss, 2008a, 2008b, **Pires et al., 2011; ***Kuribayashi et al., 2003; Tvarijonaviciute et al., 2011; Anziliero, Bazzi, Pain, Valle, \& Kreutz, 2013.

In the erythrogram, there was no statistical difference between the mean corpuscular volume, mean corpuscular hemoglobin, and mean corpuscular hemoglobin concentration among the three groups (Table 1). Furthermore, the means of these variables were within the reference range. Therefore, it is concluded that the high frequency of anemia occurring in patients with systemic diseases (56.25\% in G2) and $(75.71 \%$ in G3) was predominantly of the normocytic normochromic type (Table 1).

In animals with severe diseases (G3), the positive correlation between the globular volume and MMS variables and between 
hemoglobin and MMS (Table 2) reinforces the association between protein malnutrition (MMS $\leq 2$ ) and anemia. There was no correlation between the number of lymphocytes or platelet count and NS ( $p>0.05)$.
In animals from G2, a positive correlation was observed between TF and BCS and between TIBC and BCS (Table 2). The same type of correlation was observed between TF and MMS and between TIBC and MMS in all patients (Table 2).

\section{Table 2}

Spearman ( $r$ ) correlation values and hypothesis test (adherence to t-test) between nutritional status parameters and laboratory variables, in hospitalized dogs without systemic diseases (group $1=\mathrm{G1}$ ), with non-disabling systemic diseases (group 2 = G2) and disabling (group $3=$ G3)

$\begin{array}{cccc}\text { Group } & \text { Variables } & r & p \text {-value * } \\ \text { G1 } & \text { Cholesterol x BCS } & 0,34 & 0,01 \\ \text { G1 } & \text { Cholesterol x MMS } & 0,35 & 0,01 \\ \text { G2 } & \text { Transferrin x BCS } & 0,33 & 0,03 \\ \text { G2 } & \text { TBIC x BCS } & 0,33 & 0,03 \\ \text { G2 } & \text { Transferrin x MMS } & 0,35 & 0,02 \\ \text { G2 } & \text { TBIC x MMS } & 0,35 & 0,02 \\ \text { G2 } & \text { TSI x MMS } & -0,32 & 0,04 \\ \text { G2 } & \text { Total Protein x BCS } & 0,37 & 0,01 \\ \text { G2 } & \text { CRP/albumin x MMS } & -0,39 & <0,01 \\ \text { G3 } & \text { Transferrin x MMS } & 0,34 & 0,03 \\ \text { G3 } & \text { TBIC x MMS } & 0,34 & 0,03 \\ \text { G3 } & \text { TSI x MMS } & -0,37 & 0,02 \\ \text { G3 } & \text { TSI x BCS } & -0,34 & 0,03 \\ \text { G3 } & \text { Hematocrit x MMS } & 0,39 & 0,01 \\ \text { G3 } & \text { Hemoglobin x MMS } & 0,36 & 0,02\end{array}$

* $\mathrm{p}$-value for hypothesis test with adhered T-test (between two variables), presented only p-value $<0.05$. BMI, body mass index; BCS, body condition score; TBIC, total iron binding capacity; TSI, transferrin saturation index; CRP, C-reactive protein.

Furthermore, in G2 and G3 patients, there was a negative correlation between TSI and MMS, and in G3, this correlation with BCS was also noted (Table 2). In other words, malnourished animals (with BCS $\leq 3$ and/or MMS $\leq 2$ ) had TSI values above the average.

A positive correlation was observed between the TP and BCS in G2 (Table 2). Thus, lean animals (BCS $\leq 3$ ), in general, had low TP values $\left(<6.36 \mathrm{~g} \mathrm{dL}^{-1}\right)$. Thus, hypoproteinemia is also considered an indicator of malnutrition in systemically ill animals. However, no correlation was found between albumin level and BCS or MMS.

Regarding the CRP/albumin ratio, a very significant negative correlation was 
observed ( $p<0.01$ ) with MMS in G2 (Table 2); thus, animals with MMS $\leq 2$ (suggestive of protein malnutrition) had higher values of the aforementioned ratio (>1.81) (Table 1).

Importantly, no significant correlations were observed between albumin or CRP and clinical NS scores (BCS and MMS) in any of the groups. Therefore, in this study, the measurement of the CRP/albumin ratio was also better for the evaluation of protein catabolism and inflammation than the independent consideration of these parameters.

The values of canine transthyretin, measured using reagents designed for humans and the methodology indicated by the reagent, were below the detection limit in all tested samples, showing low reproducibility in biological material from dogs.

Only in G1, there was a positive correlation between cholesterol and NS (BCS and MMS) (Table 2). Lean animals and/or those with reduced muscle mass generally exhibited the lowest serum cholesterol concentrations measured; however, the mean was within the reference range (Table 1 ), indicating that this correlation was not clinically significant in the population studied.

There was a predominance of patients with systemic diseases presenting withanemia, especially the normocytic normochromic type, which is more common in malnutrition and inflammatory processes (Kaneko et al., 2008a; Pointer, Reisman, Windham, \& Murray, 2013; Sahin et al., 2013; Bagri et al., 2015; Sahin et al. 2016).

The association between protein malnutrition (MMS $\leq 2$ ) and anemia is secondary to impaired hemoglobin synthesis due to a lack of available substrates, especially amino acids. It is also noteworthy that the inflammatory process also contributes to the development of anemia, as the stimulus for excess myeloid cell production decreases the production of erythroblasts (Ernest, Akpan, \& Uko, 2013; Thakur, Chandra, Pemde, \& Singh, 2014; Cabada et al., 2015; Felder et al., 2016).

The association between malnutrition and anemia has been described in sick dogs (Fabretti et al., 2015; Tamimi \& Wali, 2019). A survey of 215 hospitalized dogs revealed that the more severe the malnutrition, the greater the decrease in the number of erythrocytes and hemoglobin (Fabretti et al., 2015).

The absence of a correlation between the number of lymphocytes or platelets and NS has been demonstrated in other studies (Corkins et al., 2014; Fabretti et al., 2015; Keller, 2019).

Lean (BCS $\leq 3$ ) and/or with reduced muscle mass (MMS $\leq 2$ ) and sick animals tended to have serum concentrations of TF and TBIC below the reference. Thus, in this study, TF and TIBC were considered indicators of malnutrition in systemically ill dogs. Subnormal serum concentrations of TF and TBIC in malnourished animals (especially proteins) have been described in other studies (in humans and companion animals) and are associated with decreased hepatic synthesis due to a shortage of available amino acids (Nakajima et al., 2012; Ernest et al., 2013; Nakajima et al., 2014; Jagadeswaran et al., 2019). Another explanation for these results is anemia due to chronic disease (CDA), which is often associated with malnutrition (clinically or subclinically) as systemic diseases usually lead to reduced appetite (Fabretti et al., 2015; Tamimi \& Wali, 2019). Conversely, CDA usually presents with a reduction in the TSI (Cançado 
\& Chiattone, 2002; Melo et al., 2020) and; in this study, the mean TSIs were normal in G1 and G2 and high in G3. This could raise the suspicion that the results were due to malnutrition and not the inflammatory process. Changes in iron metabolism resulting from physical exercise, as described by Ramos et al. (2019), were discarded, as the animals belonging to groups $\mathrm{G} 2$ and $\mathrm{G} 3$ were apathetic.

The negative correlation between TSI and $\mathrm{MMS}$ is well described in the literature (Ernest et al., 2013; Ghadiri-Anari, Nazemian, \& Vahedian-Ardakani, 2014). It was consistently observed that, as malnourished dogs had lower TF values, the few remaining molecules were more saturated with iron to maximize their transport.

A positive correlation was observed between the TP and BCS in G2 (Table 2). Thus, lean animals (BCS $\leq 3)$, in general, had low TP values $\left(<6.36 \mathrm{~g} \mathrm{dL}^{-1}\right)$. Thus, hypoproteinemia is also considered an indicator of malnutrition in systemically ill animals. Hypoproteinemia, as an indicator of malnutrition, has been described in humans and animals (Cooper et al., 2004; Gama-Axelsson et al., 2012; Fabretti et al., 2015; Bazzi et al., 2016; Zhang, Pereira, Luo, \& Matheson, 2017); however, many researchers consider TP as a marker of insensitive NS (Maicá \& Schweigert, 2008; Corkins et al., 2014; Nakajima et al., 2014).

Albumin is considered an insensitive marker of malnutrition by most authors, both in human and veterinary medicine, as its serum concentration drops below the reference, usually in severe situations (Gama-Axelsson et al., 2012; Nakajima et al., 2014; Fabretti et al., 2015; Felder et al., 2016). Furthermore, albumin is a negative acute-phase protein (Kaneko et al., 2008b), and its variations may reflect the inflammatory state (or even the hydration state) more than NS can. Other authors have arrived at the same conclusion in several studies (Richards et al., 2012; Corkins et al., 2014; Zhang et al., 2017; Keller, 2019).

There are few studies in humans describing the correlation between the CRP/ albumin and NS ratio and, to our knowledge, this relationship has not yet been studied in dogs. This is probably due to increased muscle catabolism, increased serum CRP concentration, and reduced albumin in inflammatory conditions (as these were sick animals), these processes could be aggravated by protein malnutrition (Richards et al., 2012; Anziliero et al., 2013; Wong et al., 2016).

Importantly, no significant correlations were observed between albumin or CRP and clinical NS scores (BCS and MMS) in any of the groups. Therefore, in this study, the analysis of the CRP/albumin ratio was also more effective for the evaluation of protein catabolism and inflammation than was the independent consideration of these parameters.

The values of canine transthyretin below the detection limit in all tested samples can be explained by the fact that the lower limit of measurement of the product is $2 \mathrm{mg} \mathrm{dL}^{-1}$ and the plasma concentration of this protein in dogs is lower $\left(0.625-10 \mu \mathrm{g} \mathrm{dL}^{-1}\right.$ ) (Nakajima et al., 2014).

Many researchers (involved in both human and veterinary medicine) consider cholesterol a marker of insensitive NS, as hypocholesterolemia manifests only at later stages, when lipid malnutrition is very intense (Assumpção \& Cabral, 2002; Corkins et al., 2014; Fabretti et al., 2015; Jagadeswaran et al., 2019; Keller, 2019). 


\section{Conclusions}

There is an evident association between malnutrition and diseases; therefore, research that makes the diagnosis of malnutrition more sensitive, objective, and practical is desirable in the routine clinical assessment of small animals. Currently, most NS markers are used only late in the chronic phase. The following are laboratory indicators of malnutrition in sick dogs: low TF, TBIC, and TP values, anemia, and elevated TSI.

The joint alterations of these markers gradually reinforced the diagnosis. However, cholesterolemia and albuminemia are not good markers of malnutrition in sick dogs. To grade the inflammatory state (important to differentiate inflammatory hypoproteinemia from protein malnutrition), measuring the CRP/ albumin ratio is more reliable than evaluating these parameters separately.

\section{Acknowledgments}

We thank the National Council for Scientific and Technological Development, Professor Mara Regina Stipp Balarin, and the entire team involved in conducting this project.

\section{References}

Agarwal, E., Ferguson, M., Banks, M., Batterham, M., Bauer, J., Capra, S., \& Isenring, E. (2013). Malnutrition and poor food intake are associated with prolonged hospital stay, frequent readmissions, and greater in-hospital mortality: results from the Nutrition Care Day survey 2010. Clinical Nutrition, 32(5), 737-745. doi: 10.1016/j. clnu.2012.11.021
Anziliero, D., Bassi, E., Pain, K. M., Valle, S. D. F., \& Kreutz, L. C. (2013). Determinação dos níveis séricos de proteína C-reativa (CRP) em cães com alterações dos parâmetros hematológicos. Ciência Animal Brasileira, 14(2), 265-272. doi: 10.5216/cab.v14i2. 9054

Assumpção, C. L., \& Cabral, M.D. (2002). Complicações clínicas da anorexia nervosa e bulimia nervosa. Revista Brasileira de Psiquiatria, 24(Suppl. 3), 2933. doi: 10.1590/S1516-444620020007 00007

Bagri, N. K., Jose, B., Shah, S. K., Bhutia, T. D., Kabra, S. K., \& Lodha, R. (2015). Impact of malnutrition on the outcome of critically ill children. Indian Journal of Pediatrics, 82(7), 601-605. doi: 10.1007/s12098015-1738-y

Baldwin, K., Bartges, J., Buffington, T., Freeman, L. M., Grabow, M., Legred, J., \& Ostwald, D. J. (2010). AAHA nutritional assessment guidelines for dogs and cats. Journal of the American Animal Hospital Association, 46(4), 285-296. doi: 10.5326/0460285

Bally, M. R., Blaser Yildirim, P. Z., Bounoure, L., Gloy, V. L., Mueller, B., Briel, M., \& Schuetz, P. (2016). Nutritional support and outcomes in malnourished medical inpatients: a systematic review and meta-analysis. JAMA Internal Medicine, 176(1), 43-53. doi: 10.1001/jamainternmed.2015.6587

Bazzi, N. B., Leal, V., Lira, H. F., Jr., Santos, J. M., Ferreira, M. G., \& Zeni, L. A. Z. R. (2016). Estado nutricional e tempo de jejum em pacientes submetidos a cirurgias colorretais eletivas. Nutrición Clínica y Dietética Hospitalaria, 36(2), 103-110. doi: 10.12873/362bazzinicole 
Bohn, A. A. (2015). Diagnosis of disorders of iron metabolism in dogs and cats. Clinics in Laboratory Medicine, 35(3), 579-590. doi: 10.1016/j.cll.2015.05.007

Brunetto, M. A., \& Carcioffi, A. C. (2015). Suporte nutricional do paciente gravemente enfermo. In M. M. Jericó, J. P. Andrade Neto, \& Kogika, M. M. (Eds.), Tratado de medicina interna de cães e gatos (pp. 4965, vol. 1). Rio de Janeiro, RJ: Gen-Roca.

Bush, B. M. (2004). Bioquímica plasmática. In B. M. Bush (Ed.), Interpretação de resultados laboratoriais para om clínico de pequenos animais (pp. 180-190). São Paulo, SP: Roca.

Bussab, W. O., \& Morettin, P. A. (2013). Inferência estatística: análise de aderência e associação. In W. O. Bussab, \& P. A. Morettin (Eds.), Estatística Básica. (8nd ed., pp. 406-426). São Paulo: Saraiva.

Cabada, M. M., Goodrich, M. R., Graham, B., Villanueva-Meyer, P. G., Deichsel, E. L., Lopez, M.,... Clinton, W. A., Jr. (2015). Prevalence of intestinal helminths, anemia, and malnutrition in Paucartambo, Peru. Revista Panamericana de Salud Pública, 37(2), 69-75.

Cançado, R. D., \& Chiattone, C. S. (2002). Anemia de doença crônica. Revista Brasileira de Hematologia e Hemoterapia, 24(2), 127-136. doi: 10.1590/S1516-848 42002000200009

Chandler, M. L., \& Gunn-Moore, D. A. (2004). Nutritional status of canine and feline patients admitted to a referral veterinary internal medicine service. The Journal of Nutrition, 134(8), 2050S-2052S. doi: 10. 1093/jn/134.8.2050S
Cooper, B. A., Penne, E. L., Bartlett, L. H., \& Pollock, C. A. (2004). Protein malnutrition and hypoalbuminemia as predictors of vascular events and mortality in ESRD. American Journal of Kidney Diseases, 43(1), 61-66. doi: 10.1053/j. ajkd.2003.08.045

Corbee, R. J., \& Kerkhoven, W. J. S. V. (2014). Nutritional support of dogs and cats after surgery or illness. Open Journal of Veterinary Medicine, 4(4), 44-57. doi: 10.4236/ojvm.2014.44006

Corkins, M. R., Guenter, P., DiMaria-Ghalili, R. A., Jensen, G. L., Malone, A., Miller, S.,... Resnick, H. E. (2014). Malnutrition diagnoses in hospitalized patients. Journal of Parenteral and Enteral Nutrition, 38(2), 186-195. doi: 10.1177/ 0148607113512154

De Luis, D. A. de, Izaola, O., Cuellar, L., Terroba, M. C., Cabezas, G., Rojo, S.,... Sagrado, M. G. (2006). Nutritional assessment: predictive variables at hospital admission related with length of stay. Annals of Nutrition and Metabolism, 50(4), 394-398. doi: $10.1159 / 000094362$

Ernest, N., Akpan, P., \& Uko, E. (2013). Reduced levels of some iron parameters of protein energy malnourished children in Calabar, Nigeria. Journal of Biology, Agriculture and Healthcare, 3(13), 114-120.

Fabretti, A. K., Fonseca, I. B., Pancieri, I. V. C., Knupp, F. C., Bordini, D. M., \& Pereira, P. M. (2014). Avaliação clínica, laboratorial e perfil eletroforético na determinação do prognóstico de cães hospitalizados. Semina: Ciências Agrárias, 35(6), 3113-3126. doi: 10.54 33/1679-0359.2015v36n1p217 
Fabretti, A. K., Fonseca, I. C. B., Coelho, A. F., Silva, C. N., \& Pereira, P. M. (2015). Evaluation of clinical, laboratory, and electrophoretic profiles for diagnosis of malnutrition in hospitalized dogs. Semina: Ciências Agrárias, 36(1), 217-230. doi: 10.5433/1679-0359.2015v36n1p217

Fabretti, A. K., Siqueira, R. C. S., Chaves, R. O., Camacho, C. A., \& Pereira, P. M. (2018). Exames laboratoriais na desnutrição de pequenos animais. Revista Clínica Veterinária, 23(133), 40-54.

Felder, S., Braun, N., Stanga, Z., Kulkarni, P., Faessler, L., Kutz, A.,... Schuetz, P. (2016). Unraveling the link between malnutrition andadverseclinicaloutcomes:association of acute and chronic malnutrition measures with blood biomarkers from different pathophysiological states. Annals of Nutrition and Metabolism, 68(3), 164-172. doi: 10.1159/000444096

Gagne, J. W., \& Wakshlag, J. J. (2015). Pathophysiology and clinical approach to malnutrition in dogs and cats. In D. L. Chan, (Ed.), Nutritional management of hospitalized small animals (pp. 117-127). Oxford, $\mathrm{OH}$ : John Wiley \& Sons.

Gama-Axelsson, T., Heimbürger, O., Stenvinkel, P., Bárány, P., Lindholm, B., \& Qureshi, A. R. (2012). Serum albumin as predictor of nutritional status in patients with ESRD. Clinical Journal of the American Society of Nephrology, 7(9), 1446-1453. doi: 10.22 15/CJN.10251011

Ghadiri-Anari, A., Nazemian, N., \& VahedianArdakani, H. (2014). Association of body mass index with hemoglobin concentration and iron parameters in Iranian population. ISRN Hematology, 52(53), 1-3. doi: 10.1155/2014/525312
Hébuterne, X., Lemarié, E., Michallet, M., de Montreuil, C. B., Schneider, S. M., \& Goldwasser, F. (2014). Prevalence of malnutrition and current use of nutrition support in patients with cancer. Journal of ParenteralandEnteralNutrition, 38(2), 196204. doi: 10.1177/0148607113502674

Ingenbleek, Y. (2019). Plasma transthyretin as a biomarker of sarcopenia in elderly subjects. Nutrients, 11(4), 895-913. doi: 10.3390/nu11040895

Ingenbleek, Y., \& Bernstein, L. H. (2015). Plasma transthyretin as a biomarker of lean body mass and catabolic states. Advances in Nutrition, 6(5), 572-580. doi: 10.3945/ an.115.008508

Jagadeswaran, D., Indhumathi, E., Hemamalini, A. J., Sivakumar, V., Soundararajan, P., \& Jayakumar, M. (2019). Inflammation and nutritional status assessment by malnutrition inflammation score and its outcome in pre-dialysis chronic kidney disease patients. Clinical Nutrition, 38(1), 341-347. doi: 10.1016/j.clnu.2018.01.001

Kaneko, J. J., Harvey, J. W., \& Bruss, M. L. (2008a). Iron metabolism and its disorders. In J. J. Kaneko, J. W. Harvey, \& M. L. Bruss (Eds.). Clinical biochemistry of domestic animals (6nd. ed., pp. 259-1285). Nova York, NW: Elsevier.

Kaneko, J. J., Harvey, J. W., \& Bruss, M. L. (2008b). Proteins, proteomics, and the dysproteinemias. In J. J. Kaneko, J. W. Harvey, \& M. L. Bruss (Eds), Clinical biochemistry of domestic animals (6nd ed., pp. 117-155). Nova York, NW: Elsevier.

Keller, U. (2019). Nutritional laboratory markers in malnutrition. Journal of Clinical Medicine, 8(6), 775-786. doi: 10.3390/jcm 8060775 
Kuribayashi, T., Shimada, T., Matsumoto, M., Kawato, K., Honjyo, T., Fukuyama, M.,... Yamamoto, S. (2003). Determination of serum $\mathrm{C}$-reactive protein (CRP) in healthy beagle dogs of various ages and pregnant beagle dogs. Experimental Animals, 52(5), 387-390. doi: 10.1538/expanim.52.387

Laflamme, D. P. (1997). Development and validation of a body condition score system for dogs. Canine Practice, 22(4), 10-15.

Lim, S. L., Ong, K. C., Chan, Y. H., Loke, W. C., Ferguson, M., \& Daniels, L. (2012). Malnutrition and its impact on cost of hospitalization, length of stay, readmission and 3-year mortality. Clinical Nutrition, 31(3), 345-350. doi: 10.1016/j. clnu.2011.11.001

Maicá, A. O., \& Schweigert, I. D. (2008). Avaliação nutricional em pacientes graves. Revista Brasileira de Terapia Intensiva, 20(3), 286-295. doi: 10.1590/ S0103-507X2008000300012

Melo, E. R., Figueiredo, S. A., Oliveira, R. T., Agripino, E. C. B., Silva, M. H. S. N. da, Domingues, H. D. C. A., \& Barbosa, J. M. A. X. (2020). Anemia of chronic disease: a review of pathophysiology, diagnosis and treatment. Brazilian Journal of Development, 6(12), 98941-98947. doi: 10.34117/bjdv6n12-400

Michel, K. E. (2015). Nutritional assessment in small animals. In D. L. Chan (Ed.), Nutritional management of hospitalized small animals (pp. 1-6). Oxford, $\mathrm{OH}$ : John Wiley \& Sons.

Michel, E. K. (2017). Nutritional assessment. In S. J. Ettinger, \& E. C. Feldman (Eds.), Textbook of veterinary internal medicine expert consult (Vol. 1, 8nd ed., pp. 18301833). Amsterdã, NH: Elsevier.

Nakajima, M., Ohno, K., Goto-Koshino, Y. G., Fujino, Y., \& Tsujimoto, H. (2014). Plasma transferrin concentration as a nutritional marker in malnourished dogs with nutritional treatment. The Journal of Veterinary Medical Science, 76(4), 539543. doi: 10.1292/jvms.13-0583

Nakajima, M., Ohno, K., Takeuchi, Y., Takeuchi, A., Nakashima, K., Fujino, Y., \& Tsujimoto, H. (2012). Usefulness of plasma transferrin levels as dynamic assessment of protein nutrition in dog. Journal of Animal Physiology and Animal Nutrition, 15(2), 65-71. doi: 10.1292/jvms.13-0583

Pimentel-Gomes, F. (2009). Testes não paramétricos. In: F. Pimentel-Gomes (Ed.), Curso de estatística experimental (15nd ed., pp 377-394). São Paulo, SP: ESALQ.

Pires, L. S. A., Dittrich, R. L., Souza, A. C., Bertol, M. A. F., \& Patrício, L. F. L. (2011). Parâmetros utilizados na avaliação do metabolismo do ferro em cães. Ciência Rural, 41(2), 272-277. doi: 10.1590/S01 03-84782011000200015

Pointer, E., Reisman, R., Windham, R., \& Murray, L. (2013). Starvation and the clinicopathologic abnormalities associated with starved dogs: a review of 152 cases. Journal of the American Animal Hospital Association, 49(2), 101107. doi: 10.5326/JAAHA-MS-5762

Ramos, B. S. N., Moraes, V. S., Pinheiro, R. M., Souza, V. R. C., Alves, J. C., \& Coelho, C. S. (2019). Effects of resistance training on serum iron, total iron-binding capacity and transferrin saturation in police working dogs. Comparative Exercise Physiology, 15(4), 253-258. doi: 10.3920/CEP190032 
Richards, C. H., Roxburgh, C. S. D., MacMillan, M. T., Isswiasi, S., Robertson, E. G., Guthrie, G. K.,... McMillan, D. C. (2012). The relationships between body composition and the systemic inflammatory response in patients with primary operable colorectal cancer. Plos One, 7(8), e41883. doi: $10.1371 /$ journal.pone.0041883

Sahin, S., Tasar, P. T., Simsek, H., Çicek, Z., Eskiizmirli, H., Aykar, F. S.,... Akcicek, F. (2013). The prevalence of anemia and malnutrition and the relationship between anemia and malnutrition. European Geriatric Medicine, 4(1), 133. doi: 10.10 16/j.eurger.2013.07.438

Sahin, S., Tasar, P. T., Simsek, H., Çicek, Z., Eskiizmirli, H., Aykar, F. S.,... Akcicek, F. (2016). Prevalence of anemia and malnutrition and their association in elderly nursing home residents. Aging Clinical and Experimental Research, 28(5), 857-862. doi: 10.1007/s40520015-0490-5

Saker, K. E., \& Remillard, R. L. (2010). Critical care nutrition and enteral-assisted feeding. In M. Hand, C. D. Tratcher, R. L. Remillard, P. Roudebush, \& C. Novotny (Eds.), Small animal clinical nutrition (5nd ed., pp. 351-390). Topeka, KS: Mark Morris Institute.

Slee, A., Birch, D., \& Stokoe, D. (2016). The relationship between malnutrition risk and clinical outcomes in a cohort of frail older hospital patients. Clinical Nutrition ESPEN, 15(1), 57-62. doi: 10.1016/j. clnesp.2016.06.002

Sullivan, D. H. (2001). What do the serum proteins tell us about our elderly patients? The Journals of Gerontology. Series $A$, Biological Sciences and Medical
Sciences, 56(2), M71-M74. doi: 10.1093/ gerona/56.2.m71

Szöke, D., \& Panteghini, M. (2012). Diagnostic value of transferrin. Clinica Chimica Acta; International Journal of Clinical Chemistry, 413(15-16), 1184-1189. doi: 10.1016/j.cca.2012.04.021

Tamimi, N. S. M., \& Wali, A. A. (2019). Health problems of Iraqi Police dogs referred to Baghdad Veterinary Hospital during 20152017. Veterinary World, 12(7), 1046-1051. doi: 10.14202/vetworld.2019.1046-1051

Thakur, N., Chandra, J., Pemde, H., \& Singh, V. (2014). Anemia in severe acute malnutrition. Nutrition, 30(4), 440-442. doi: 10.1016/j.nut.2013.09.011

Tvarijonaviciute, A., Martinez, S., Gutierrez, A., Ceron, J. J., \& Tecles, F. (2011). Serum acute phase proteins concentrations in dogs during experimentally short-term induced overweight. A preliminary study. Research in Veterinary Science, 90(1), 3134. doi: 10.1016/j.rvsc.2010.05.008

Veena, A., Amit, D., Sonagra, B., Rekha, M. B., \& Jayaprakash, M. D. S. (2013). Study of serum iron, TIBC, transferrin saturation and ferritin in iron deficiency anemia in tertiary care hospital. International Journal of Pharmacy and Biological Sciences, 3(1), 14-23.

Wissler, C. (1905). The Spearman correlation formula. Science, 22(558), 309-311.

Wong, T. C., Su, H. Y., Chen, Y. T., Wu, P. Y., Chen, H. H., Chen, T. H.,... Yang, S. H. (2016). Ratio of C-reactive protein to albumin predicts muscle mass in adult patients undergoing hemodialysis. PLOS One, 11(10), e0165403. doi: 10.1371/journal. pone.0165403 
World Small Animal Veterinary Association (2013). Muscle condition score. Ontario, On: Author.

Freeman, L., Becvarova, I., Cave, N., MacKay, C., Nguyen, P., Rama, B.,... van Beukelen, P. (2011). WSAVA Nutritional assessment guidelines. Journal of Small Animal Practice, 52(7), 385-396. doi: 10.1111/ j.1748-5827.2011.01079.x
Zhang, Z., Pereira, S. L., Luo, M., \& Matheson, E. M. (2017). Evaluation of blood biomarkers associated with risk of malnutrition in older adults: a systematic review and meta-analysis. Nutrients, 9(8), 829-849. doi: 10.3390/nu9080829 